\title{
POTENSI ORGAN TUMBUHAN SEBAGAI INDIKATOR ASAM BASA
}

\author{
S. Hafidhawati Andarias \\ Prodi Pendidikan Biologi, Fakultas Keguruan dan Ilmu Pendidikan \\ Universitas Muhammadiyah Buton, Jl. Betoambari No. 36 Baubau. \\ E-mail: fidha.andarias@gmail.com
}

\begin{abstract}
Abstrak
Indikator sintesis atau buatan merupakan indikator kimiawi yang dijual di pasaran dengan beberapa kelemahan seperti menimbulkan polusi kimia, ketersediaan bahan dan harga yang relatif mahal. Hasil kajian ini menunjukkan bahwa beberapa organ tumbuhan bahkan tumbuhan liar ataupun bagian yang tidak umum digunakan dalam kehidupan sehari-hari, dapat dimanfaatkan sebagai indikator asam basa pengganti indikator sintesis. Bagian tumbuhan yang dapat dimanfaatkan adalah bagian yang berwarna terang karena adanya kandungan antosianin di dalamnya yang diekstrak menggunakan metode maserasi. Jenis dan bagian tumbuhan yang dimanfaatkan adalah bunga belimbing wuluh, bunga dadap merah, bunga pukul empat, daun bayam merah, kulit ubi ungu, dan bunga karamunting. Pembuatan indikator dalam bentuk larutan lebih mudah rusak dan berbau setelah penyimpanan yang lama sehingga pembuatan indikator kertas lebih banyak dipilih karena keunggulan yang dimiliki seperti: mudah diamati, hemat penggunaan, praktis, dan lebih murah.
\end{abstract}

Kata kunci: asam basa, antosianin, indikator alami

\begin{abstract}
Synthesis or artificial indicators are chemical indicators that are sold in the market with several disadvantages such as chemical pollution, availability of materials and relatively high prices. The results of this study indicate that some plant organs and even wild plants or parts that are not commonly used in daily life, can be used as acid-base indicators instead of synthesis indicators. Plant parts that can be utilized are brightly colored parts because of the anthocyanin content in them which is extracted using the maceration method. The types and parts of the plants used are wuluh starfruit, red dadap flowers, four o'clock flowers, red spinach leaves, purple yam skin, and caramunting flowers. Making an indicator in the form of a solution is more easily damaged and smells after a long storage so that the making of paper indicators is more chosen because of the advantages it has such as: easy to observe, efficient use, practical, and cheaper.
\end{abstract}

Keywords: acid base, anthocyanin, natural indicator. 


\section{SANG PENCERAH}

Volume 4, Nomor 2, Agustus 2018, Hlm. 64-69

\section{S. Hafidhawati Andarias: Potensi Organ Tumbuhan sebagai ...}

\section{Pendahuluan}

Asam dan basa merupakan hal sering kita dengar dalam kehidupan sehari-hari, khususnya dalam pelajaran kimia baik ditingkat sekolah menengah pertama hingga sekolah menengah atas, bahkan sampai ke jenjang perguruan tinggi. Istilah asam berasal dari bahasa Latin acetum yang berarti cuka, sedangkan kata basa berasal dari bahasa Arab yang artinya abu (Petrucci, 1987). Mengetahui rasa dari larutan asam dan sama tidak selalu aman dilakukan dengan uji organoleptik mengingat sebagain dari larutan asam dan basa bersifat toksik jika masuk ke dalam tubuh. Oleh karena itu, dibutuhkan indikator untuk mengetahui apakah suatu larutan bersifat asam, basa, ataupun netral. Indikator asam basa adalah suatu senyawa organik yang dapat berubah warna dengan berubahnya $\mathrm{pH}$, biasa digunakan untuk membedakan suatu larutan bersifat asam atau basa dengan cara memberikan perubahan warna pada larutan asam dan basa (Fessenden \& Fessenden, 1999). Terdapat berbagai jenis indikator asam basa yang biasanya digunakan sebagai indikator asam basa di laboratorium diantaranya adalah kertas lakmus (lakmus merah dan biru), indikator universal, larutan indikator, dan indikator alami, sedangkan dalam titrasi asam basa sering diganakan indikator phenolptalin (pp) dan indikator metil orange (mo).

Menggunakan kertas lakmus dalam pengujian larutan asam basa menunjukkan kertas lakmus merah akan berwarna merah dalam larutan yang pHnya lebih kecil dari 5,5 dan berwarna biru dalam larutan yang pHnya lebih besar dari 8. Dalam larutan yang pHnya 5,5 sampai 8 warna lakmus adalah kombinasi warna merah dan biru. Batas-batas $\mathrm{pH}$ ketika indikator mengalami perubahan warna disebut trayek indiktor (Salirawati, 2005).

Indikator sintesis atau buatan merupakan indikator kimiawi yang dijual di pasaran dengan beberapa kelemahan seperti menimbulkan polusi kimia, ketersediaan bahan dan harga yang relatif mahal (Nurhayati dkk, 2010). Namun, penggunaan indikator sistesis tersebut ternyata dapat digantikan dengan penggunaan indikator alami. Saat ini telah dilakukan beberapa penelitian yang menunjukkan bahwa indikator asam basa juga dapat diperoleh dari bahan alami dengan memanfaatkan zat warna antosianin yang ada pada tumbuhan. Indikator asam basa alami dapat dibuat dengan mengesktrak bagian dari tanaman, seperti batang, daun, bunga, dan buah. Berdasarkan deskripsi di atas, fokus penelitian ini tentang jenis tumbuhan yang diekstrak untuk dijadikan sebagai indikator asam basa alami.

\section{Metode Penelitian}

Penelitian ini digunakan jenis/pendekatan penelitian yang berupa Studi Kepustakaan (Library Research). Studi kepustakaan yang dimaksud adalah mengumpulkan berbagai sumber referensi dari berbagi jurnal-jurnal penelitian.

\section{Pembahasan}

\section{Pemanfaatan Organ Tumbuhan sebagai Indikator Asam Basa}

Berbagai hasil penelitian mengenai pemanfaaatan bahan alam/tumbuhan sebagai indikator alami telah dilakukan. Diantara penelitian tersebut adalah:

\section{Belimbing Wuluh (Averrhoe bilimbi L.)}

Pengujian dengan asam sitrat menunjukkan perubahan warna merah cerah, pada natrium karbonat menunjukkan perubahan warna biru-hijau, dan pada natrium karbonat tidak berwarna. Indikator kertas terbuat dari kertas saring yang dicelupkan dalam ekstrak bunga Averrhoe bilimbi L. Pemilihan ekstak bunga Averrhoe bilimbi L karena memiliki warna yang 


\section{SANG PENCERAH}

Volume 4, Nomor 2, Agustus 2018, Hlm. 64-69

\section{S. Hafidhawati Andarias: Potensi Organ Tumbuhan sebagai ...}

mencolok dengan warna ungu yang tegas. Indikator alami dalam bentuk larutan biasanya tidak bertahan lama, mudah rusak, dan menimbulkan bau yang tidak sedap. Untuk mengatasinya, kita dapat membuatnya dalam bentuk kertas indikator atau kertas dibuat seperti kertas lakmus (Lestari, 2016).

\section{Bunga Dadap Merah (Erythrina crista- galli L.)}

Potensi bunga dadap merah sebagai indikator asam basa dilakukan menggunakan ekstrak etanol hasil maserasi (Rahmawati et al., 2016), dan Kurniawati et al., 2015). Dalam pengujiannnya, ekstrak diuji dalam asam-basa, larutan buffer, dan dibandingkan dengan fenolftalein untuk asam kuat dengan basa kuat sedangkan metil jingga basa lemah dengan asam kuat. Berdasarkan hasil penelitian ini, indikator ekstrak bunga merah dadap pada asam kuat berwarna merah, sedangkan pada asam lemah berwarna pink, dan pada basa kuat berwarna hijau gelap dan basa lemah ungu. Selanjutnya, dalam larutan buffer, indikator ekstrak bunga merah dadap memberikan empat kelompok perubahan warna, yaitu warna merah pada $\mathrm{pH} 1$ ke $\mathrm{pH}$ 6, tidak berwarna pada $\mathrm{pH} 7 \mathrm{ke} \mathrm{pH}$ 9, coklat pada $\mathrm{pH} 10$ dan biru pada $\mathrm{pH} 11$ ke $\mathrm{pH}$ 12. Selain itu, untuk mencapai titik akhir titrasi, indikator ekstrak bunga merah dadap memberikan hasil yang serupa dengan indikator perbandingan (Rahmawati et al., 2016).

\section{Bunga Pukul Empat (Mirabilis jalappa)}

Bunga pukul empat juga merupakan salah satu tanaman yang dapat digunakan sebagai indikator asam basa alami (Fadhila, 2107, dan Shishir, 2008). Ekstraksi bunga pukul empat menggunakan pelarut etanol $7 \%$ dengan pengeringan kertas indikator asam basa pada suhu $70^{\circ} \mathrm{C}$ menunjukkan warna yang lebih kontras dalam membedakan larutan asam kuat, asam lemah, basa kuat, dan basa lemah. Perubahan warna yang dihasilkan yaitu gradasi warna ungu pada larutan asam dan gradasi warna kuning pada larutan basa (Fadhila, 2107).

\section{Bayam Merah (Alternantera amoena voss)}

Anternatif indikator asam basa alami juga dapat menggunakan bayam merah (Izonfuo, 2006; Ratnasari, 2014). Pemanfaatan bayam merah sebagai salah satu indikator asam basa alami adalah dengan menggunakan daunnya. Kertas indikator $\mathrm{pH}$ dibuat dengan menggunakan kertas saring biasa dengan lama perendaman dalam ekstrak adalah 5 menit. Penggunaan kertas saring biasa lebih baik daripada menggunakan kertas saring Whatman no. 1 (Ratnasari, 2014).

\section{Ubi Ungu}

Bagian dari ubu ungu yang dapat digunakan sebagai indikator asam basa alami adalah kulit. Ekstrak kulit ubi ungu sebagai indikator asam-basa alternatif karena dapat menunjukkan perubahan warna pada kondisi asam maupun basa seperti halnya kertas lakmus. Bahkan, kertas indikator yang direndam hasil maserasi menggunakan metanol dengan suhu pengeringan bahan $70^{\circ} \mathrm{C}$ memiliki kelebihan dibandingkan dengan kertas lakmus, yakni mengalami perubahan warna pada asam lemah dan basa lemah. Kertas lakmus hanya mampu membedakan suatu larutan bersifat asam atau basa saja. Sedangkan kertas indikator dari ekstrak kulit ubi ungu, mampu membedakan antara larutan asam kuat dengan asam lemah dan larutan basa kuat dengan basa lemah, berdasarkan gradasi warna yang dihasilkan saat pengujian. Warna menjadi bright pinkketika dicelupkan pada asam kuat, teh hijau pada basa kuat, shocking pink pada asam lemah, dan mauves pada basa lemah (Mahanani, 2017). 


\section{SANG PENCERAH}

Volume 4, Nomor 2, Agustus 2018, Hlm. 64-69

\section{S. Hafidhawati Andarias: Potensi Organ Tumbuhan sebagai ...}

\section{Buah Karamunting (Rhodomyrtus tomentosa)}

Indikator asam basa dari karamunting diperoleh dengan mengolah buah ini dengan pelarut air dan alkohol. Hasilnya, indikator karamunting memberikan warna merah dalam larutan asam dan biru dalam larutan basa, Untuk kertas indikator karamunting, indikator yang paling asam adalah warna merah muda dan indikator paling basa adalah warna biru (Indira, 2005).

Berdasarkan data di atas, terlihat bahwa metode yang digunakan untuk mendapatkan kandungan antosianin dalam tubuh tumbuhan adalah dengan metode ekstraksi menggunakan berbagai jenis pelarut, seperti air, alkohol/etanol, dan methanol. Jika dibandingkan pembuatan indikator dalam bentuk larutan yang mudah rusak atau berbau setelah penyimpanan yang lama, pembuatan indikator kertas lebih banyak dipilih karena keunggulan yang dimiliki seperti: mudah diamati, hemat penggunaan, praktis, dan lebih murah.

\section{Kandungan Antosianin}

Uraian di atas menunjukkan bahwa berbagai organ tumbuhan dapat dimanfaatkan sebagai alternatif indikator asam basa seperti bunga, daun, buah, dan kulit buah, Pemanfaatan tumbuhan sebagai pengganti indikator sintesis adalah dengan memanfaatkan kandungan antosianin pada tumbuhan tersebut. Antosianin adalah metabolit sekunder dari famili flavonoid, dalam jumlah besar ditemukan dalam buahbuahan dan sayuran (Talavera et al, 2004). Senyawa golongan flavonoid termasuk senyawa polar dan dapat diekstraksi dengan pelarut yang bersifat polar pula. Beberapa pelarut yang bersifat polar diantaranya etanol, air dan etil asetat. Kondisi asam akan mempengaruhi hasil ekstraksi. Keadaan yang semakin asam apalagi mendekati $\mathrm{pH} 1$ akan menyebabkan semakin banyaknya pigmen antosianin berada dalam bentuk kation flavilium atau oksonium yang berwarna dan pengukuran absorbansi akan menunjukkan jumlah antosianin yang semakin besar (Moulana, 2012).

Antosianin adalah kelompok pigmen yang menyebabkan warna kemerahmerahan, letaknya di dalam cairan sel yang bersifat larut dalam air (Nollet, 1996). Secara kimia, antosianin merupakan turunan struktur tunggal, yaitu sianidin dan semuanya terbentuk dari pigmen sianidin dengan penambahan atau pengurangan gugus hidroksil, metilasi, dan glikosilasi (Harborne, 2005). Antosianin dari berbagai tanaman semakin banyak digunakan dalam industri makanan dan obat-obatan karena warnanya manarik dan aman bagi kesehatan. Warna antosianin sangat dipengaruhi oleh struktur antosianin serta derajat keasaman (Jacman et al.,1987).

\section{Kesimpulan}

Simpulan penelitian ini bahwa Berdasarkan hasil kajian ini, terlihat bahwa beberapa organ tumbuhan bahkan tumbuhan liar ataupun bagian yang tidak umum digunakan dalam kehidupan seharihari, dapat dimanfaatkan sebagai indikator asam basa pengganti indikator sintesis. Bagian tumbuhan yang dapat dimanfaatkan adalah bagian yang berwarna terang karena adanya kandungan antosianin di dalamnya. Bagian-bagian yang dimaksud antara lain: bunga belimbing wuluh, bunga dadap merah, bunga pukul empat, daun bayam merah, kulit ubi ungu, dan bunga karamunting. 


\section{SANG PENCERAH}

Volume 4, Nomor 2, Agustus 2018, Hlm. 64-69

\section{S. Hafidhawati Andarias: Potensi Organ Tumbuhan sebagai ...}

\section{Daftar Pustaka}

Fadhilla, N.N.O. 2017. Pemanfaatan Ekstrak Mahkota Bunga Pukul Empat sebagai Indikator Asam Basa Alternatif dengan Variasi Suhu Pengeringan dan Jenis Pelarut. Skripsi. Universitas Muhammadiyah Surakarta. Solo.

Fessenden, R. dan Fessenden, J.S. 1999. Kimia Organik Jilid 2. Erlangga. Jakarta.

Harborne, 2005. Encyclopedia og Food and Colour Additives. CRC Press, Inc. New York.

Herbie, T. 2015. Kitab Tanaman Berkhasiat Obat: 226 Tumbuhan Obat untuk Penyembuhan Penyakit dan Kebugaran Tubuh. Octopus Publishing House. Yogyakarta.

Indira, Cita. 2015. Pembuatan Indikator Asam Basa Karamunting. Kaunia Vol. Xi, No. 1.

Izonfuo, L.T., Fekamhorhobo, G.K., Obomanu, G.K., Daworiye, L.T. 2006. Acid Base Indicator Properties of Dye from Local Plant: Basella and Hibiscus rosa-sinensis. Journal of Applied Sciences and Environment Managemen, Vol 10, No. 1, pp 5-8.

Jacma, R.L., Yada, R.Y. Tung, M.A., dan Speers, R.A. 1987. Separation and Chemical Properties of Anthocyanins Used for Their Quantitattive adn Qualitattive Analysis - A Riview. Journal of Food Biochemistry 11: 179 - 208.

Kurniawati, Mappiratu, dan Ahmad, R. 2015. Kajian Ekstrak Etanol Bunga Tanaman Johar (Cassia siamea L.) sebagai Bioindikator Asam Basa. Natural Science, 4 (2), 128 - 143.

Lestari, Puji. 2016. Kertas Indikator Bunga Belimbing Wuluh (Averrhoa bilimbi) untuk Uji Larutan Asam Basa. Jurnal Pendidikan Madrasah, Vol. 1, No. 1.

Mahanani, S. 2017. Pemanfaatan Kulit Ubi Ungu sebagai Indikator Asam Basa Alternatif dengan Variasi Suhu dan Pengeringan dan Jenis Pelarut. Skripsi. Universitas Muhammadiyah Surakarta. Solo.

Moulana, R, Efektivitas Penggunaan Jenis Pelarut dan Asam dalam Proses Ekstraksi Pigmen Antosianin Kelopak Bungan Rosella, Jurnal Forum Teknik , Universitas Syah Kuala, Darussalam, Banda Aceh, Vol 4, No 3, 2012.

Nollet, L.M.L. (1996). Handbook of Food Analysis: Physical Characterization and Nutrient Analysis. Marcell Dekker Inc, New York.

Nurhayati S., Matsjeh S., Anwar, C., dan Raharjo, T.J. 2010. Indikator Titrasi Asam Basa dari Ekstrak Bunga Sepatu (Hibiscus rosa-sinensis L). Agritech, Vol 30, No. 3.

Petrucci, R. 1987. Kimia Dasar. Jakarta: Erlangga.

Rahmawati, Nuryanti, S., dan Ratman. 2016. Indikator Asam-Basa dari Bunga Dadap Merah (Erythrina crista-galli L.). J urnal Akademika Kimia. Vol. 5, No. 1.

Ratnasari, D. 2014. Pemanfaatan Ekstrak Daun Bayam Merah (Alternantera amoena voss) dalam Bahan Pembuatan Kertas Indikator $\mathrm{pH}$ pada Mata Pelajaran Kimia di Madrasah Aliyah. Skripsi. Universitas Islam Negeri Sultan Syarif Kasim Riau. Pekanbaru.

Shishir, M.N., Laxman, J.R., Vinayak, R.N., Jacky, D. R., Bhimrao, G.S., (2006). Use of Mirabilis jalappa L. Flower Extract as 


\section{SANG PENCERAH}

Volume 4, Nomor 2, Agustus 2018, Hlm. 64-69

S. Hafidhawati Andarias: Potensi Organ Tumbuhan sebagai ...

A Natural Indicator in Acid Base Titration. Journal of Pharmachy Recearch, Vol 1 Issue 2.

Talavera, S., Felgine, C., dan Texier, O., (2004), Bioavailability of a bilberryanthocyanin Extract and its impact on plasma antioxidant capacity in rats.46 aLaboratoirede Pharmacognosie, Facultéde Pharmacie, Clermont-Ferrand, France, bLaboratoire des Maladies Métaboliques et des Micronutriments, Institut National de la Recherche Agronomique de ClermontFerrand/TheixSaint - Genès Champanelle, France. Journal of the Science of Food of Agriculture. 